\title{
Serum alkaline phosphatase fractionation as an aid to diagnosis
}

\author{
K. B. COOKE AND JOAN F. ZILVA \\ From the Department of Chemical Pathology, Westminster Medical School, London
}

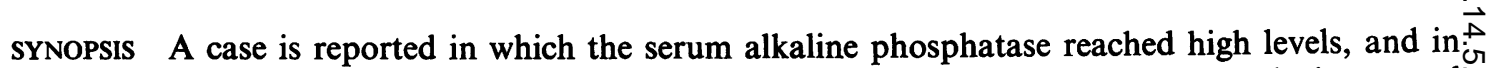
which the differential diagnosis between hepatic secondary deposits and osteomalacia provedir difficult by the usual means. Separation of the alkaline phosphatases by starch grain electrophoresis was used as an aid to differential diagnosis.

The positive identification of secondary deposits in the liver by other than clinical means is sometimes difficult. Recent work by Keiding (1959) indicates that the serum alkaline phosphatase activity can be separated electrophoretically into components of hepatic and of bony origin, a technique which might be used in those cases presenting with a greatly raised level of enzyme of doubtful origin. Cases in which the diagnosis cannot be made on careful assessment of clinical, radiological, and routine biochemical evidence will be rare, but we present such a problem which clearly illustrates the validity and utility of the phosphatase fractionation.

\section{HISTORY AND CLINICAL EXAMINATION}

M.O., aged 73, was admitted to the Westminster Hospital under Mr. F. d'Abreu on 8 September 1960. In 1951, she had had a partial gastrectomy for a chronic, benign gastric ulcer, after which she developed diarrhoea, and this had continued with such severity that she had up to seven motions a day. In 1958, she had an annular growth at the rectosigmoid junction resected. This was shown histologically to be a grade II adenocarcinoma penetrating muscle (Dr. A. Morgan). During laparotomy the liver was examined and found to contain no palpable secondary deposits. In the week preceding operation the mean 24-hour faecal fat excretion on three specimens was 7.4 g. The serum potassium level was $3.2 \mathrm{mEq}$./1. and total protein $5.7 \mathrm{~g} . / 100 \mathrm{ml}$. On this evidence she seemed to have some malabsorption. On the present admission she complained that she had become worse and that she had lost half a stone in three weeks. She ate little, and this, combined with the malabsorption, could have accounted for her symptoms. The liver, spleen, and kidneys were not palpable, and there was no obvious lymphadenopathy.

INVESTIGATIONS She was anaemic with a haemoglobin

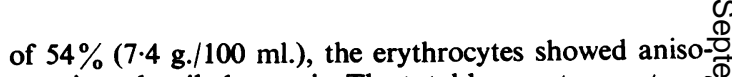
cytosis and poikylocytosis. The total leucocyte count was $\stackrel{\overparen{D}}{\exists}$ $11,400 /$ c.mm., of which $93 \%$ were polymorphonuclears, with an occasional myelocyte, and a 'shift to the left'. Platelets appeared normal. Bone marrow aspiration $\overrightarrow{0}$ showed a toxic marrow. There was an increase of nucleated red cells but no megaloblasts. No malignant cells were seen. Radiologically the bones showed noo evidence of metastases.

The serum potassium level was now $2.8 \mathrm{mEq} . / 1$ calcium $8.0 \mathrm{mg} . / 100 \mathrm{ml}$., and phosphate $2.8 \mathrm{mg} . / 100 \mathrm{ml}$ The serum alkaline phosphatase level was markedly raised to 87 K.-A. units, the pseudocholinesterase level was 32 units (normal 55-100 units), and lactic dehydrogenase 520 and 540 units on two occasions (normal 0-500 units). The urine contained a trace of urobilinogen, but other routine liver function tests were. normal. Electrophoresis of serum showed a low albumito level and relatively raised $\alpha_{1}$ and $\gamma$ globulin levels. The total serum protein level was $5.20 \mathrm{~g} . / 100 \mathrm{ml}$., and albuming $2.93 \mathrm{~g} . / 100 \mathrm{ml}$.

TREATMENT AND PROGRESS In the absence of definitive evidence of metastases the patient was treated as a case of malabsorption with large doses of calciferol, iron, and folic acid, and also with plasma and blood transfusionso There was temporary clinical improvement during which. the alkaline phosphatase level, which had risen to 96 K.-A. units, fell steadily to 76 units, and the serum Ca and $\mathrm{PO}_{4}$ rose to $9.0 \mathrm{mg} . / 100 \mathrm{ml}$. and $5.0 \mathrm{mg}$. $/ 100 \mathrm{mfo}$ respectively on 24 November 1960 . The serum proteif and haemoglobin levels rose only temporarily followin transfusion, and the clinical improvement was shorto lived and she died on 1 December.

\section{FRACTIONATION OF ALKALINE PHOSPHATASE}

METHODS Serum, $2.5 \mathrm{ml}$, was dialysed overnight again

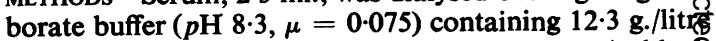
$\mathrm{MgSO}_{4} \cdot 7 \mathrm{H}_{2} \mathrm{O}$, and then fractionated by starch block electrophoresis (Kunkel, 1954) in a tray $25 \mathrm{~cm} . \times 5 \mathrm{~cm}$. 
$1 \mathrm{~cm}$. After running for six hours at 500 volts (during which time the temperature was maintained below $10^{\circ} \mathrm{C}$.) the slab was sectioned at $1 \mathrm{~cm}$. intervals and each segment extracted with two lots of $2 \mathrm{ml}$. of $0.9 \% \mathrm{NaCl}$ to which had been added $12 \cdot 3 \mathrm{~g}$./litre $\mathrm{MgSO}_{4} \mathbf{7} \mathrm{H}_{2} \mathrm{O}$. Protein content was estimated in each tube spectrophotometrically at $210 \mu$ (Tombs, Souter, and Maclagan, 1959), using a 1 in 10 dilution with saline. Alkaline phosphatase was estimated on the Auto Analyzer (Technicon Instrument Co. Ltd.) using a modification of the King-Armstrong method (unpublished work). Finally paper electrophoresis was carried out on those fractions showing alkaline phosphatase activity.

RESULTS Alkaline phosphatase fractionation were carried out before and after treatment with calciferol. Figure 1 shows the electrophoretic protein and alkaline phosphatase patterns obtained with two sera, before and after treatment with calciferol, recovery of alkaline phosphatase being approximately $50 \%$.

The fall in total activity from 96 to $76 \mathrm{~K}$.-A. units between the first and second fractionations was entirely due to depression of $\beta$ globulin activity. The $a_{1}$ peak remained essentially constant while the $\alpha_{2}$ peak increased.

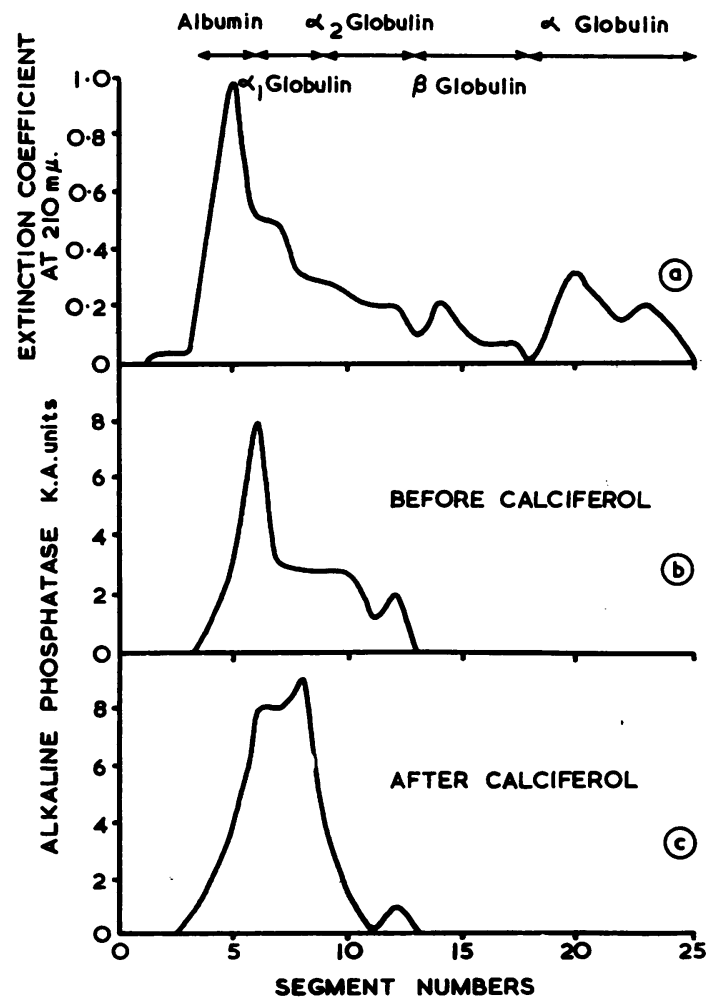

FIG. 1. (a) The protein pattern (b) The alkaline phosphatase pattern before treatment with calciferol. The phosphatase activity in segments 11 to 13 is that usually referred to as $\beta$ phosphatase (c) The alkaline phosphatase pattern after treatment with calciferol.

\section{POST-MORTEM FINDINGS}

Dr. D. H. MacKenzie found that the liver was slightly enlarged with almost the whole of the right lobe replaced by solid tumour tissue. The left lobe showed multiple small metastases. There was no evidence of bony metastases.

\section{DISCUSSION}

It was thought unlikely that a serum alkaline phosphatase level of 96 K.-A. units was due solely to osteomalacia and that a possible explanation was the presence of hepatic metastases from the rectal carcinoma. Although there was no clinical, radiological, or haematological evidence for this, the small urinary urobilinogen excess and the abnormal serum enzyme values supported the hypothesis but further evidence seemed desirable.

Keiding (1959) has shown that serum alkaline phosphatase can be separated into three components by starch grain electrophoresis. Of these, the $\beta$ globulin activity is associated with phosphatases arising from bone whereas the $\alpha_{1}$ and $\alpha_{2}$ globulin activities are associated with liver phosphatase. His results indicate that this method might prove of value in detecting liver metastases. Rosenberg (1959), using a similar technique, failed to resolve the $\alpha_{2}$ and $\beta$ phosphatases and found that in a series of 60 cases the $\alpha_{1}$ fraction never contributed more than $16 \%$ of the total activity. Our case showed some $50 \%$ of the total activity in the $\alpha_{1}$ peak, a finding confirmed by paper electrophoresis of the active fractions, but the $\beta$ globulin activity was never grossly raised.

The evidence of the phosphatase fractionations was that the initially high value was due to enzyme travelling with $\alpha_{1}$ and $\alpha_{2}$ globulins and was, therefore, mainly of hepatic origin. Although a grossly abnormal $\alpha_{1}: \alpha_{2}$ phosphatase ratio was observed we feel that we have insufficient experience with other conditions to draw any conclusions from this finding. The fall after calciferol therapy was entirely in the fraction originating from bone ( $\beta$ globulin), suggesting that this also had been slightly raised at first. It appeared, therefore, that there was osteomalacia but no bony metastases, and that the enzyme came predominantly from liver deposits. This was amply confirmed by the very temporary response to therapy and by the necropsy findings.

We thank Mr. F. d'Abreu for permission to study this case, Professor N. F. Maclagan for his help, Mr. B. Allen for technical assistance, and Dr. J. Humble for allowing us to report the haematological findings.

\section{REFERENCES}

Keiding, N. R. (1959). Scand. J. clin. Lab. Invest., 11, 106.

Kunkel, H. G. (1954). Meth. biochem. Anal., 1, 141.

Rosenberg, I. N. (1959). J. clin. Invest., 38, 630.

Tombs, M. P., Souter, F., and Maclagan, N. F. (1959). Biochem. J., $73,167$. 